\title{
Preliminary Results of the 2017 Season in the Amazonian Earthen Structures Known as Geoglyphs
}

(1) Grup d'Investigació GRAM. Dpt. Prehistòria, Arqueologia i H $\mathrm{H}^{\mathrm{a}}$ Antiga. Universitat de València. adiez@uv.es

(2) Fundação de Cultura e Comunicação Elias Mansour. ivandrar@yahoo.com.br

(3) Universidade Federal do Acre.tjgfernandes@yahoo.com.br

(4) Instituto Chico Mendes de Conservação da Biodiversidade. fluvio.mascarenhas@icmbio.gov.br

(5) Instituto de Patrimonio Histórico e Artístico de Brasil (IPHAN).mardinisobrinho@ gmail.com

(6) Empresa Brasileira de Pesquisa Agropecuária - EMBRAPA. evandro.figueiredo@embrapa.br

The first season of fieldwork by the Universitat de València Estudi General (UVEG) and the Universidade Federal do Acre (UFAC) research joint team has made significant progress in the knowledge of earthen structures built in the Amazonian landscape, popularly known as geoglyphs. Progress has been:

a) remarkable in some aspects of research field, among them the first application of high-precision surveying to some of the structures,

b) important with respect to understanding the general phenomenon and

c) outstanding in applying a new survey strategy.

The addition of a new structure within the Reserva Extrativista Chico Mendes, on the Santa Rosa land, located by one of us (Fluvio de Sousa Mascarenhas) and some novelties like the finding of ceramic remains on the surface of the structures Xipamanú 2 and Piçarreira both in the municipality of Xapurí. Finally, the visit to the monuments of the colony of Nossa Senhora de Nazaré has served to verify the importance of that group (fig. 1).

Based upon the current knowledge of the phenomenon (Rampanelli 2016) we can argue that the earthen structures of trenches in the western Amazon are located almost entirely in the triangle between the Purus rivers at the North and the Xipamanu Abunã system at the South before this ends into the Madeira river. The western boundary is more vague but goes not further of the longitude $70 \mathrm{~W}$. Both the Purus and the Madeira are great amazon rivers that today, even at the end of the dry season, are important geographical barriers. Only a few structures are outside of this area and most of them are either atypical or misinterpreted when exploring remote images. The latter is the case of Nak $02 \mathrm{RO}$ that was visited by us, in the 2017 season, being considered as a false positive.

Earthen structures in western Amazonia have been treated with some profusion in recent years (see Saunaluoma 2013 and Rampanelli 2016 for a complete list of references) mainly due to the fact that their monumentality is such that they can be discovered with some experience and patience in, for instance, Google Earth (GE) or Google Maps. This can be the origin of facing two parallel planes in their knowledge, the first one could called the virtual plane and other one the ground truth. The first plane includes geoglyphs that have been remotely localized mainly through the images of Google Earth and which existence has been notified to the IPHAN in a 


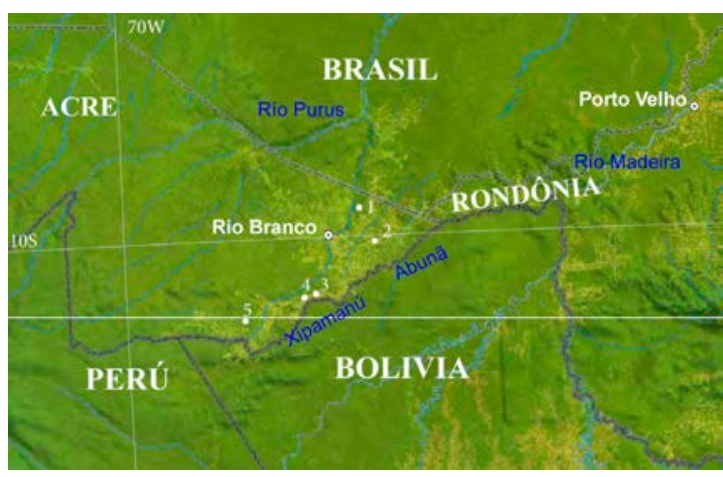

Fig. 1: Places cited in the text: 1) Nossa Senhora de Nazaré, 2) Chiquinho, 3) Piçarreira, 4) Xipamanú, 5) Santa Rosa.

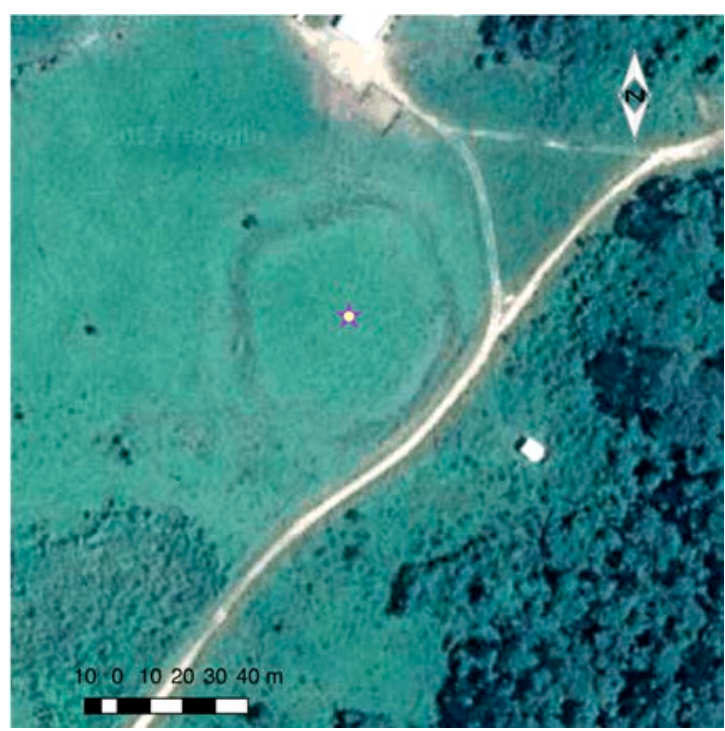

Fig. 2: Subquadrangular structure in Santa Rosa Colony (Reserva extrativista Chico Mendes).

more or less formal manner. Not only GE images, whose resolution is variable in this vast territory of the western Amazonia, are used. Some have also been found with other similar services like Apple Maps or Bing. Alceu Ranzi and Nakahara have contributed with an important number of structures to the current knowledge (Schaan et al. 2010). When an earthen structure is remotely localized it is labeled after the name of the person that have discovered it, some additional information related to their geographical position ( $\mathrm{RO}=$ Rondonia and Amazonas $=\mathrm{AM}$, or $\mathrm{BO}=$ Bolivia) is added to the name. One of the main drawbacks, of this method, is that there is not way to know if an area has been already surveyed or not (beyond the knowledge of each surveyor). Needless to say, that there can be, and there is surely other people doing that kind of survey, as a simple search for the terms geoglyphs and Acre on YouTube show. Such a search provides tens of videos related to the phenomenon uploaded for all kind of people from journalists or scholars to volunteers.

To try to alleviate the problem of not knowing what areas have been already surveyed, what we believe a new strategy of consistent surveying has been designed. First we have drawn virtual transects $200 \mathrm{~m}$ apart of each other in some areas. The results of the new method are being tested on the territory of the Reserva extrativista Chico Mendes. Transects are drawn into a Geographic Information System within the area of interest (e.g. the Extractive Reserve or a municipality) and then numbered and assigned to each surveyor. To perform the test in Resex Chico Mendes the resulting transects were distributed among a group of 10 students from the UFAC who will participate in an introduction to field archeology workshop during the first semester of 2018. The practical implementation of this simple task consists in providing each one of the surveyors with a $\mathrm{kml}$ file with their transects, although the task can also be performed from the QGIS itself with the OSM plugin that lets to load satellite images from different providers (Bing, Google Earth, ...). Another way to perform the task that requires a little more of training before hand, it is loading the transects in GPX format to the OpenStreetMap server. The advantages of this system is that the structures located can be drawn immediately in OpenStreetMap and thus be subject to audit not only by the project coordinators but also from the community ${ }^{1}$. The horizon of this research team is to replicate the tasking manager of the Human OpenStreetMap Team (HOT).

In the second case, there are the monuments that have been mainly visited by research teams coordinated by Dra. Denise Schaan and Dr. Pärssinen (Schaan et al. 2010). Once these teams visited each site and gather some initial measurements and a detailed description of the structure they names are changed and their real existence communicated to the IPHAN.

But back to the result of our work in the months of October and November 2017 in the Brazilian states of Rondonia and Acre, they include the discovery of a new subquadrangular structure on the Santa Rosa land, inside the Resex Chico Mendes (fig. 2). It has a trench deeper than the average one of 1,40 $\mathrm{m}$ (Rampanelli 2016), the 
Fig. 3: Chiquinho circle, in the north part are clearly visible the new structures located. a) Current Maps Google view, b) New ortophoto, c) Digital surface model d) Chiquino after processing the new data.

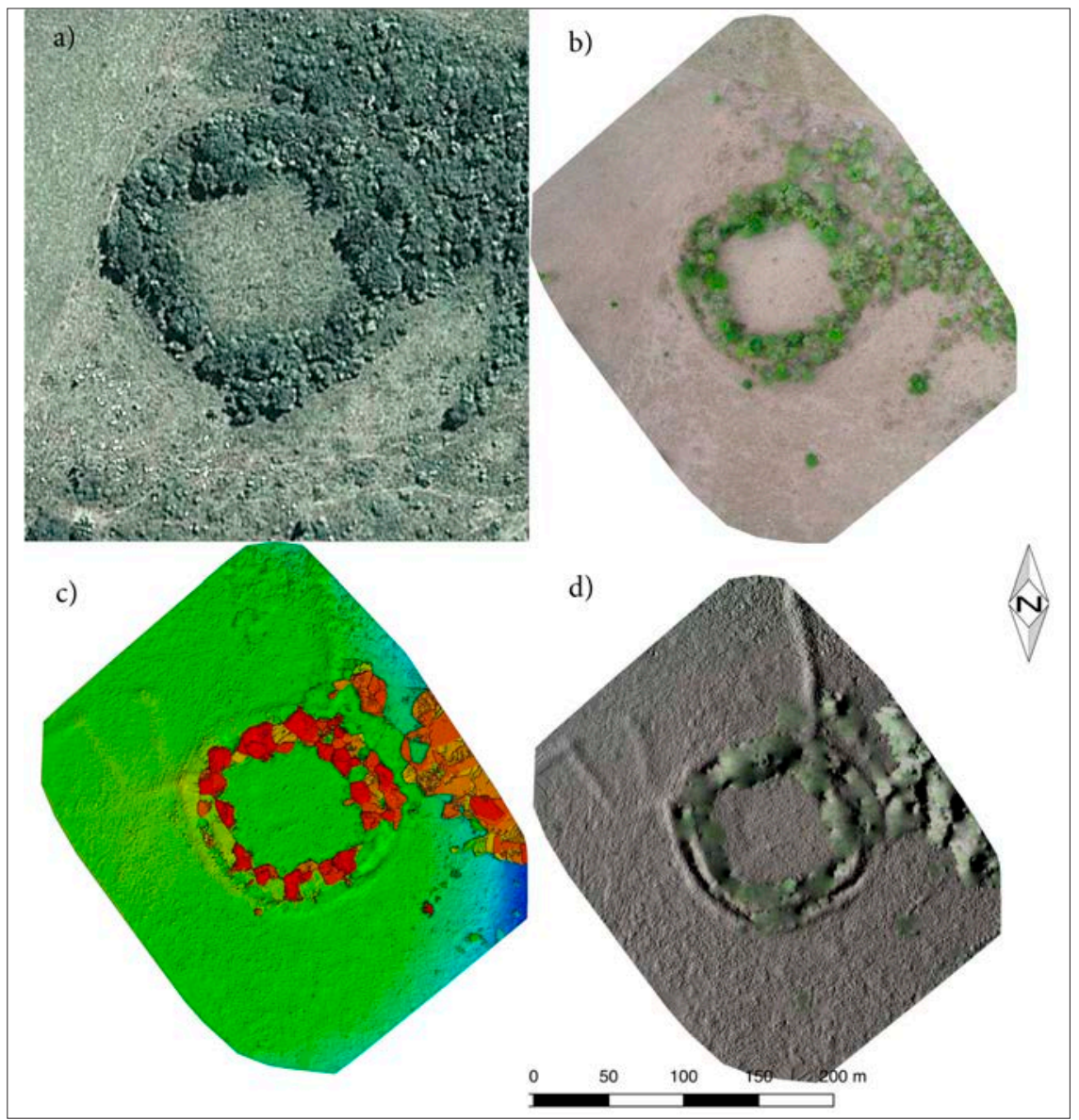

maximum width of the structure including the outer ends of the external belt is $75 \mathrm{~m}$. The width of the trench (as measured between the top parts of the inner and outer walls) varies between $13,5 \mathrm{~m}$ in the undisturbed part and less that seven in the recently modified SE area.

The fact that this new monument is within the territory of the Reserva Extrativista Chico Mendes has important consequences because it is one of the few of a total of 527 known geoglyphs, in the state of Acre, which is on public land in a well protected area. That will allow the IPHAN (Institute of Historical and Artistic Heritage of Brazil) to make immediate arrangements for their declaration as part of the Brazilian list of archaeological monuments, which would make it the first archaeological site of the Acre state to receive such protection.

A LIDAR flight has been carried out on the monument of Chiquinho (fig. 3). The initial intention of this kind of survey was simply to have a detailed topography of it and analyze the costs of having it. Fortunately enough, the treatment of the resulting digital terrain model has revealed the potential of the method for detailed analysis of the structures morphometry. After processing the resulting data, the location of linear structures, that gives the Chiquinho circle a character of a far more complex structure that what was thought until now, has been revealed. Those new features complete the northern part of the monument (fig. 3, d). The importance of such finding lies in the fact that show that the structures located in remote exploration could be more complex than previously envisaged. The ground test at the site confirmed the existence of earth walls highlighting the need to analyze, in some detail, each one of the more than 800 geoglyphs known until now. Before performing this precision surveying, only one topography, performed with total station in the monument of Tequinho, had been published (Saunaluoma \& Virtanen 2015) whose resolution, although not 


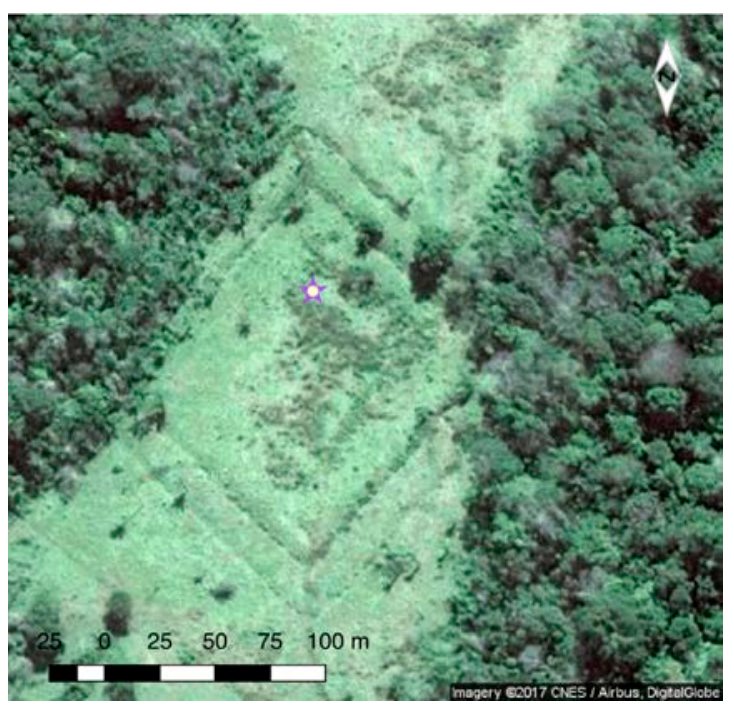

Fig. 4: Quadrangular structure in the Nossa Senhora de Nazaré Colony.

specified, is less than $1 \times 1 \mathrm{~m}$, compared to $2,5 \mathrm{~cm} \times 2,5$ $\mathrm{cm}$ of the Chiquinho one. In Tequinho and others structures some features beyond the limits of the main one, namely roads and paths (Rampanelli et al. 2017) have already been located.

Eventually, the fieldwork was completed with three visits to the Nossa Senhora de Nazaré (NSN) group. This group is composed of three quadrangular structures whose maximum size varies between $230 \mathrm{~m}$ and the 160 $\mathrm{m}$. The most interesting of these three structures is the NSN III is composed of two quadrangular structures separated by a corridor of 20 meters on average (fig. 4). We have proceeded to propose that those monuments should be registered by the IPHAN and from now on they should be known as Nossa Senhora de Nazaré I (the one known as Nakahara 15), Nossa Senhora de Nazaré II (Nakahara 16) and Nossa Senhora de Nazaré III (before Nakahara 18).

In short, the work carried out by the multidisciplinary research team led by the UVEG and the UFAC has shown that there is still much of field work to be done in the western Amazonia earthen structures known as geoglyphs.

\section{NOTE}

1. Placing the fact that the first commentary to mapping the Santa Rosa geoglyph at OpenStreetMaps occurs within hours of the edition, demonstrates the potential of collaborative work on the OpenStreetMap platform.

\section{REFERENCES}

HOT (2017): Hot Tasking Manager. https://tasks.hotosm.org RAMPANELLI, I. (2016): Las estructuras de tierra delimitadas por zanjas en la Amazonía Occidental, Tesis Doctoral, Universitat de Valencia (http://roderic.uv.es/bitstream/handle/10550/55877/TESIS_Ivandra_Rampanelli_2016.pdf).

RAMPANELLI, I.; DIEZ CASTILLO, A.; FERNANDES, T. J. G.; MARDINI, J. (2017): Conhecendo os caminhos ou trilhas dos geoglifos pré-colombianos sul amazônicos, JAMAXI 1(1), 113-123 (http://revistas.ufac.br/revista/index.php/jamaxi/article/view/1440).

SAUNALUOMA, S. (2013): Pre-columbian earthwork sites in the frontier region between Brazil and Bolivia, Southwestern Amazon, Tesis Doctoral, Universidad de Helsinki (https:// helda.helsinki.fi/bitstream/handle/10138/40907/saunaluoma_dissertation.pdf).

SAUNALUOMA, S.; VIRTANEN, P. K. (2015): Variable models for organization of earthworking communities in Upper Purus, southwestern Amazonia: Archaeological and ethnographic perspectives, Tipiti: Journal of the Society for the Anthropology of Lowland South America 13(1), 23-43 (https://digitalcommons.trinity.edu/cgi/viewcontent. cgi?referer=https://scholar.google.co.uk/citations?hl=en \& user=J_1dsikAAAAJ\&view_op=list_works\&sortby=pubd ate \&httpsredir $=1 \&$ article $=1196 \&$ context $=$ tipiti).

SCHAAN, D.; BUENO, M.; RANZI, A.; BARBOSA, A.; SILVA, A.; CASAGRANDE, E.; RODRIGUES, A.; DANTAS, A.; RAMPANELLI, I. (2010): Construindo paisagens como espaços sociais: o caso dos geoglifos do Acre, Revista de Arqueologia 23(1), 30-41 (http://www.revista.sabnet.com. br/revista/index.php/SAB/article/download/286/268). 